\title{
Public justification analysis of Russian renewable energy strategies
}

\section{Salonen, Hilma Annikki}

2018-04-02

Salonen, H A 2018 , ' Public justification analysis of Russian renewable energy strategies ' , Polar Geography , vol. 41 , no. 2 , pp. 75-86 . https://doi.org/10.1080/1088937X.2018.1457730

http://hdl.handle.net/10138/309825

https://doi.org/10.1080/1088937X.2018.1457730

cc_by_nc_nd

acceptedVersion

Downloaded from Helda, University of Helsinki institutional repository.

This is an electronic reprint of the original article.

This reprint may differ from the original in pagination and typographic detail.

Please cite the original version. 


\section{Public Justification Analysis of Russian Renewable Energy Strategies}

The Russian renewable energy industry has not yet succeeded in breaking through into the domestic market despite its potential, particularly in remote Arctic settlements. This article examines broad issues that influence national policy-makers and provides an analysis of the type of objectives that are emphasized in Russian energy policies. It can be assumed that the priorities behind these objectives have a more stable status than more concrete plans to boost the use of renewables, since they often fail to materialize. In order to discover these priorities, I analyze several relevant policy-making documents with the help of public justification analysis, a method developed to examine public claims made in favor of a certain cause, and the commonly known values that the claimmakers refer to in order to convince others. This paper reveals that Russian energy policy documents tend to emphasize concrete, technical tasks over more abstract, holistic goals. In addition, industrial needs dominate all policies, even those related to socio-economic or environmental issues. I conclude that the tendencies listed above may prevent fundamental structural change in the Russian energy industry, despite the potential of renewable energy, especially in the Arctic regions.

Keywords: Russia; energy; renewables; energy policy; Arctic

\section{Introduction}

The prospects for developing and using renewable energy in Russia might seem unnecessary in a country that is so inextricably involved in oil and gas production. Extractive industries are the backbone of the country's policy, both domestic and foreign. On the one hand, fossil fuels offer Russian citizens security in the shape of cheap electricity, and on the other, they represent a lion's share of the state budget. Natural gas products are highly subsidized, almost closing the market to competitors (Øverland and Kjærnet 2009). The seemingly endless energy resources, centralized energy markets revolving mainly around a few big and often state-run companies, and the current scarcity of international investors has left little room for pilot projects on renewable energy. In some cases, however, investing money on alternative projects 
might save more money than sustaining the old systems. This article addresses these types of arguments that are involved in the shaping of values behind new energy policies in order to explore which aspects of renewable energy may have a more competitive edge than others. In order to identify them, I examine the reasons presented in official documents that favor supporting renewable energy development with the help of public justification analysis.

In the Russian Arctic, many far-flung settlements are dependent on statesubsidized fuel deliveries from the so-called Northern Delivery system (or in Russian, Severnyi zavoz), which has been working since the Soviet times despite being both very costly to maintain and prone to accidents and delays. Thus, finding new alternatives for these small villages, with the help of local renewable energy sources, would seem a cost-effective plan (Øverland 2010). For example, in the Murmansk district, a longplanned pilot project has combined a wind farm, diesel power installations, and solar batteries, inspiring other villages in the region to follow suit. As a result, its residents enjoyed a 24-hour cycle of electricity for the first time instead of relying on a diesel generator that only provided an 8-hour cycle and was often short on fuel (Kireeva 2014). For the longer term future, significant investments in wind power are envisioned and the first offshore wind farm has been built in the White Sea (The government of Karelia 2016) and Rosatom is planning to invest almost 80 million roubles in the domestic wind energy market, which also has a lot of unused potential along the coast of the Arctic Ocean (Rosatom Newsletter 2016, IRENA 2017). Due to Russia's potential and on-going projects, renewable energy development in Russia's Arctic regions deserves greater attention by scholars.

Despite these first steps, a stable supply of heat and electricity has traditionally been prioritized over energy efficiency or energy saving goals, even if these energy 
delivery chains require more state subsidies consumed, especially in isolated Arctic settlements (WWF 2017). Since renewable energy sources have long been placed in the margins of national energy policies, their role has usually been more about supporting the existing energy delivery networks than actually restructuring them. Therefore, as the global strategic importance of renewable energy development is rising in the aftermath of the Paris climate agreement, it is topical to ask what type of a role is reserved for the renewables in the Russian energy policy sphere in the long run. Previous research on the Russian renewable industry has largely concentrated on various factors, including commercial, legal, and structural aspects, affecting the prospects of the new industry and potential niches in the market (e.g. Pristupa and Mol 2015, Vasileva et al. 2015, Øverland and Kjærnet 2009). I aim to look beyond this technical framework by examining the issue from the public justification viewpoint. This approach offers a new framework for research on renewable energy policy that is able to go beyond description of specific target programmes to explore the norms and values to which decision-makers, industry actors and, ultimately, citizens are expected to adhere.

The paper proceeds by first introducing the issues linked to the development of renewable energy sources (RES) in policy documents. Then, I briefly examine the theory and methodology employed to depict and identify claims of public justification in these documents, and to recognize the most influential ones. I discuss the concept of legitimacy, which is central to the process of public justification. In analysis of the results, I focus on issues of energy security, energy efficiency, and their relevance to overall Arctic development since they feature strongly both in the relevant literature and the documents studied. I examine some key development priorities emerging from the data and discuss how they fit into a global context. Finally, the conclusion examines the broader importance of the results of the public justification analysis. 


\section{Grounds for Renewable Energy Support}

Despite their relative abundance, Russian energy resources are unevenly scattered around the country, and the cost of their extraction is increasing (IPB Inc. 2015). Furthermore, despite being profitable, the oil and gas industry is notoriously inefficient, and a significant amount of energy is lost in different stages of energy consumption. Because of these challenges, improving energy efficiency and increasing the share of renewable energy sources have been linked together in the Federal Energy Efficiency Law of 2009 and Federal Heat Law of 2010, so that increase in renewable energy use is seen as a way to improve energy efficiency (Boute 2012). This kind of institutional push has caused the drafting of several policy-making documents and target programs, where the use of RES is integrated both into targets for better energy efficiency and also energy savings (Tynkkynen and Aalto 2012). This article examines these documents to better understand the broader priorities of Russian energy industry modernization.

Although some of the first pilot projects have been successful, various reforms and action plans have mostly failed during the last ten years in their attempts to create effective and sufficient measures to support industries utilizing RES (Tynkkynen and Aalto 2012). This is mostly because institutional work has been insufficient, inefficient, and full of loopholes, while investments made have not been financially viable (Pristupa and Mol 2015, Boute 2013). Corruption also plays a role by affecting the overall conditions of energy policy-making and results in, for example, difficulties in obtaining reliable information about the ineffectiveness of remote heating and electricity power plants (Øverland \& Kjærnet 2009). The insufficiency of reforms is reflected in the disparity of official renewable energy objectives and the small number of projects finished and still running after some years. Despite the size of some priority projects for example in wind energy, these types of innovations do not change the structural 
handicaps plaguing the overall development of the industry, nor the political mind-set behind broader policy-making decisions. Hence, in order to better understand the real priorities and potential of the modernization of the Russian energy system, it is necessary to find out about the more durable legacy of energy strategies in cases where their goals fail to materialize. Considering the difficulties that energy efficiency projects have faced this far, it might be that improving energy security, providing a more stable supply of energy, might be a stronger object of interest for the Russian policy-makers in the end.

The literature on energy security has broadened the term significantly from its traditional reference to the stability of oil and gas supply (e.g. Turton and Barreto 2006, Constantini et al. 2007, Greene 2010). The International Energy Agency and other actors currently consider supplies of biomass and hydropower in their calculations on energy security (International Energy Agency 2011), as renewable energy resources become more competitive (Yergin 2006). The diversity and regularity of supply, however, remain central to the discussion. Cherp and Jewell (2011) argue that for this reason, knowledge from the sphere of natural sciences, engineering, or economics has also been incorporated into the (geo)political discourse, often oversimplifying the issues at hand. Cherp and Jewell offer a more complex framework by defining three different approaches to energy security: sovereignty, robustness, and resilience. Sovereignty is concerned with control over energy supplies, robustness with diversity of resources and upgrading infrastructure, and resilience focuses on predicting and withstanding disruptions.

\section{Arctic Renewable Energy}


Based on strategic documents, such as the Arctic strategy of Russia, energy security in the Russian Arctic generally relates to the stability of fuel supply. I argue that while Russia examines alternative sources of heat especially regarding its northernmost communities and thus aims to make its Arctic communities more resilient, it simultaneously broadens its definition of energy security, albeit slightly. The process would entail a switch from sovereignty over energy resources to robust and resilient readiness towards unpredictable factors. Energy security's status (and, consequently, the status of affordable heat and electricity) as a concept evoking wide social resonance is understandable, considering the severe winters of Arctic Russia (Bridge 2014). As a result, improving energy security may also entail strengthening the state's presence and control over a region. Recently, even international actors, such as the EU, have wished that an increase in the use of RES, for example wood-based biomass, would lead to a more balanced and equal territorial development within Russia. However, these plans often fail to take consider the special geographic characteristics of the remote Russian wood-producing regions, namely population scarcity (Tynkkynen 2014). Therefore, it is unlikely that modernization of both the economy and industries would expand without the state's strong involvement.

Since the prevailing market and political conditions are clearly not in favor of the development of renewable energy products and the generation of a project's revenue may take several years, RES pilot projects in Russia are greatly dependent on investments from the federal budget (WWF 2017). The small number and limited influence of local actors and the slowness of repayments on investments in the industry means that the subsidies paid to renewable energy projects by the government risk seeming useless. Under these conditions, some kind of a legitimization process in necessary. 
A successful legitimization process would result in the RES industry, including its current supporting mechanisms, becoming an institutionalized practice, both in societal and economic terms. It would become one of those practices "that persist and are reinforced because they are taken for granted, normatively endorsed, and backed by authorized powers" (Scott 1995, p. 62). Here, I treat established energy practices as institutions. I view legitimacy as the outcome of a long process of attempts to safeguard the political and social acceptance of new policies and methods utilizing renewable energy resources. A stable status of legitimacy may only be achieved if the majority of

entrepreneurs, interest groups and, above all, decision makers internalize the values of a new practice, such as that of energy efficiency, and accept them as appropriate and desirable. This status would considerably help implementing the decrees already made and finding much needed domestic investors, which are key issues plaguing the prospects of renewables.

\section{Methodological Approach}

This research looks into the process of legitimizing renewable energy investments with the help of the theoretical framework developed by sociologist Luc Boltanski and economist Laurent Thévenot (1991) in their work On Justification. This approach considers the various of ways of convincing others that one's opinions or actions are more just than those of the opposing side. Justification is done by referring to the common good, and, ultimately, to moral arguments. This approach is valuable for this article because it enables revealing the values considered as relevant in the Russian energy policy sphere, and by doing so, assessing what characteristics a renewable energy project should encompass in order to secure federal interest and investments in Russia. 
Boltanski and Thévenot analyze methods of justification by identifying seven categories of values that are generally recognized in the society. These categories, then, work as a set of principles that are shared by both the ones justifying their cause and the people they are aiming to win over, thus granting the categories significant social and moral worth. The principles consist of "worlds", namely fixed frames of justification, that are listed as stemming from sources of domestic, inspired, fame, civic, industrial, market and ecological value. In the context of this article, for example, the industrial value of a renewable energy source may refer to its tangible material worth such as heating efficiency or potential as a back-up in the case of an accident. Market value refers to monetary benefits, for example to the profits that are expected from green-tech products or to the need for economic reforms. Civic value is understood as increasing social wellbeing and may refer to the greater wellbeing of an Arctic community, for example, to the creation of new jobs or improved housing conditions. Ecological value, in the context of the sources of this article, is understood as fighting against greenhouse gas emissions, or in general as finding cleaner methods of producing energy. Other categories of value were later proven irrelevant within the scope of this study.

To operationalize this theory and these concepts, Tuomas Ylä-Anttila and Anna Kukkonen (2014) worked on a new methodological approach named public justification analysis (PJA), which aims to detect and frame the arguments stemming from the above-mentioned worlds of justification. Ultimately, this approach not only enables examination of the tools that policy-making documents may use to strive towards a state of legitimacy, but also comparing and observing which aspects are emphasized over others. The unit of analysis in PJA is a 'claim,' a fixed concept originally developed originally in the sphere of political claims analysis. Making a claim essentially means expressing political opinion in the public sphere as a strategic action (Koopmans 2006). 
This analysis focuses on claims made for the general public, that is, on attempts to influence future economic and social development of the society. The claims presented in policy-making documents are usually political, which in this context means purposeful, strategic and public (Koopmans 2006). Concentrating on these types of claims makes it possible to identify and organize the categories of justification under which each claim belongs to. First, passages in energy policy documents containing the word 'renewable' (возобновляемый) and the abbreviation for renewable energy sources (BЭР) were searched, excluding hits referring solely to one specific source of energy, such as hydropower. Secondly, claims were identified from these passages following Koopman's (2006) criteria for a methodological approach on claim-making analysis. The same passage may contain a combination of claims. Then, using the methodological tools developed by Ylä-Anttila and Kukkonen (2014), analysis and organization of the claims were based on different categories of justification. (The codebook is available from the authors by request).

This process allows their organization in a table that clearly presents prevailing values in the legitimization process of renewable energy products, along with the degree of diversity of the frames of justification.

\section{Analysis of Policy Documents}

I chose to study six documents, all post-dating the presidential decree of 2008, which set a target for reducing energy waste, and containing not only information about the use of RES, but also claims made in their favor. The documents are: (1) Main Statements of the Energy Strategy of Russia for the period up to 2035, published in 2014 by the Russian Ministry of Energy; (2) Basics of the state policy of the Russian Federation in the Arctic for the period till 2020 and for further perspective, published in 
2009 and adopted by President Medvedev. (later also: the Arctic Strategy); (3) The Concept for Long-term Social and Economic Development up to 2020, published in 2008 by the Russian Ministry of Economic Development; (4) The Climate Doctrine, published in 2009 and prepared by several experts and ministries; (5) The development strategy of the Arctic zone of the Russian Federation and national security for the period up to 2020, published in 2013 and adopted by President Putin; and (6) The strategy of energy efficiency in municipalities, published in 2008 by several experts in companies and institutions.

\section{[t]Table 1 near here[/t]}

Many claims found in the documents refer to a clear source of justification, such as cutting down on emissions, while some are more ambiguous or combine two different methods of justification. To provide a framework for further analysis of the table, I give examples of each type of claim. These examples show how the use of renewable energy sources could profit the nation.

The civic frame of justification draws on collective wellbeing in its claim that economic modernization will develop from using more RES, via increase in employment, industrial innovation, and quality of social conditions. Justifications based on market values refer to cutting expenses (by reducing transports costs and distribution), and supporting the markets or industries (for example, by optimizing the economic mechanisms of the 'Northern Freight' or achieving the international standard of RES-related high-tech). The civic development framework allows combining market and civic worlds, for example by claiming that using RES optimizes the economic mechanisms of the Arctic energy deliveries, thus improving the public administration system of the socio-economic development. The industrial frame of justification 
contains most claims and also most variation between them. While energy savings may refer to the decreasing the use of fossil fuels, the need to improve energy efficiency or energy security by renewables is often not fully elaborated although often mentioned. This frame also encompasses claims for improved living conditions, defined here as the creation of comfortable urban and rural environments. Claims related to ecology concentrate on reducing emissions, either generally or in particular cases.

The table above shows the sources for public justification in the Russian policymaking documents mainly concentrating on issues that are more material than social, and more concrete than abstract. As the literature on energy transition also suggests, endeavors reflected in the strategies tend to focus on fixing the loopholes in the existing system, such as reaching energy savings targets, or becoming the leading producer of sustainable high technology. More claims carry this type of claims of justification than any other, and also considerably more dispersion exists within this group. For example, while the environment is often the basis of justification, these claims solely focus on reducing emissions, which is a much more concrete task than, say, 'creating a better world for future generations'. The increased use of renewables is mostly considered an aid to bigger projects, such as regional development (by increasing the amount of jobs, for example), or the diversification of the fuel complex, or the boosting the national economy. Literature on the subject suggests (e.g., Øverland and Kjærnet 2009, Tynkkynen and Aalto 2012) that RES projects often involve attempts to improve energy efficiency (especially since claims for energy savings are sometimes also partly related to these attempts) and energy security, especially regarding Northern peripheries.

Claims of improved energy efficiency and energy security are frequent as they often intersect with other claims. Examples include those pertaining to socio-economic development (emphasizing either the social or the economic part), or the support of 
RES to local industries by ensuring a steady flow of fuel. Interestingly, this applies also to documents such as the "Concept of Long-term Social and Economic Development until 2020". This document's analysis of the utility of RES concludes that their main potential might lie in turning the economy into a more 'innovation-based' and competitive direction, instead of pointing out some socio-economic justifications. "The Climate Doctrine" of 2009 agrees with this statement by mentioning how investing in renewable energy would act as "a catalyst for the dynamic technological modernization of the whole Russian economy." In other words, the predetermined needs of the entire Russian economy tend to dominate discussions not only on renewable energy, but also on energy efficiency and energy security.

Many of the problems that the Russian economy is expected to solve by using renewables involve the nation's geographical difficulties. These mostly relate to problems of distance, and the consequential dependencies on imports and vulnerabilities. These issues are most visible in documents discussing activities in the Arctic, particularly the Northern Freight system and the risks involved in dealing with long distances, severe weather conditions, and dependence on imported (fossil) fuels. In these circumstances, utilizing local fuels could remove major obstacles from the path of Arctic industries, by offering the regions previously unexperienced energy security. By ensuring the flow of work force to the North, small niche projects may have strategic importance.

When talking about the Russian energy policy-making efforts, it is essential to remember that despite its resources, Russia is not a monolithic actor in the energy field. Despite the highly centralized decision-making structure, the decisions made reflect also other views than those of the authorities, for example those of specialized energy and service companies. Furthermore, when studying the reality of Russian energy policy, 
regional, national, interregional and international levels must be equally considered. Therefore, even though strategies and their objectives are drafted by the governing bodies, they reflect more broad-based interests (Aalto 2014). Thus, it can be assumed that even though the policy-making documents are directed to a relatively limited audience, they nevertheless reflect norms and values that the whole society is expected to take into consideration as well. In addition, the documents studied here point out not only national but also global trends. In other words, despite their technical appearance, they operate in a world of public justification, where the struggle for winning over the 'general opinion' is taken seriously. As an indication of their connection to the wider world, these documents have often clustered with similar policy-making initiatives in the international or national level.

The flow of Arctic strategies started in 2006 among Arctic Council members, and by 2011, all had put their Arctic policies in a written form (Heininen 2011). As for the Russian Climate doctrine, its existence is not only required by the United Nations Convention, obliging all countries to develop policies and measures regarding climate issues, but was also published just before the UN Copenhagen Climate Conference of 2009. Similarly, the new Russian Climate Action Plan preceded the 2015 UN Climate Conference in Paris. "The Energy strategy", "Strategy of energy efficiency in municipalities" and "Concept for long-term social and economic development up to 2020" seem to follow domestic policy decisions. Domestic socio-economic development, as well as energy policies, are key issues for a state, and so the first Energy strategy was approved already in 1992. As for the "Strategy in energy efficiency", it clearly derives from the Presidential decree of 2008, which addressed to greater benefits of renewables for the first time. However, the decree was probably 
issued also to reflect global trends, such as the collective resolution to promote energy efficiency, signed by the G8 countries in 2005 .

Which characteristics of the development of renewables are unique to Russia and which are more universal? A study comparing government promotion of renewable energy technologies in the US, Japan and Germany as three big industrial actors suggests that the interplay between economic and ecologic incentives is likely a universal characteristic to the discourse on the subject, although to a varying degree (Jordan-Korte 2011). Even though these three countries have approached the question in their own individual ways, the study notes that what is common is that they all have had influential programs on renewable energy and reasons to stay on the course in spite of the fluctuating fossil fuel prices.

As noted previously, energy transitions are hardly ever smooth operations, even at the planning stage. In its attempts to utilize renewable energy source in order to sustain the old energy complex by filling some gaps in its reliability instead of restructuring it, Russia is acting in accordance with the general principles of energy transition. For example, the role of niches and pilot projects is strongly emphasized in the literature on energy transition from the multi-level perspective (e.g. Geels 2002, 2012). New technologies are typically both expensive and slow to deliver initial results, making niches a valuable way of gaining legitimacy from the general public in the initial stages of new renewable energy projects.

Based on the results from the strategic documents, the key difference emerging here is the way how Russia consciously separates itself from the core debate on energy transition - that is, how to build a low-carbon society - by focusing on material issues such as securing energy supply or supporting the development of the domestic industry. The Russian position generally passes over possible larger implications of renewable 
energy usage. As a result, the idea of energy transition is bound to stay superficial in the public discussion, concentrating on few niches available and not (yet) offering a vision that would really help Russia to meet its official objectives in renewable energy usage.

\section{CONCLUSION}

The prevailing consensus following the Paris Agreement of 2015 has been that investing in bioenergy is key in order to succeed in the energy transition towards a lowcarbon society. Replacing the use of fossil fuels, especially coal, is often considered the most straightforward way to mitigate climate change and meet the targets of the Agreement. On the other hand, carbon neutrality of certain forms of bioenergy, mainly the burning of wood and other biomass, has possibly been releasing more carbon dioxide emissions than reducing them (Vergragt, Markusson and Karlsson 2011). In other words, the concept of energy transition is often left to be defined separately in each case. In most cases, it is a complex process characterized by controversy, negotiations, and setbacks (Jørgensen 2012). The pre-development phase is generally slow. Irrespective of the strategic planning quality, the completion of this phase may take cycles, which are only partially controlled by the government. For these reasons, attempts at energy transitions often start by improving existing technologies rather than replacing them (Rotmans, Kemp and Van Asselt 2001).

In countries where both the diversity of the energy complex and the involvement of the civil society are low, the transition process is even more prone to failure (Binder, Mühlemeier and Wyss 2017). Russian modernization projects have traditionally struggled with these issues, causing inadequate diversity of solutions available, as a result of highly centralized decision-making machinery, and a lack of financial instruments and local stakeholders (Pristupa and Mol 2015). These factors, along with 
the country's status as an oil and gas exporter, point in Russia suffering from a carbon lock-in. This term was coined by Gregory Unruh (2000) and refers to economies that are unable to move towards more efficient and clean technologies despite their availability. The inertia of physical, economic and social constraints is simply too strong. In other words, if a society is accustomed to using fossil fuels, breaking the cycle is very difficult (Unruh 2000, Seto, Davis, Mitchell, Stokes, Unruh and ÜrgeVorsatz 2016).

The inertia supporting the use of fossil fuels is implicitly present in the official policy-making documents in the form of the narrow frame into which the reasons to support renewable energy sources must fit in. Public justification analysis has traditionally examined public debates in the media, but by showing its ability to extract new aspects from policy-making documents, it has proven to be a more versatile method. Researchers familiar with public justification analysis have noted its suitability as a method to study international comparisons and unearth otherwise invisible characteristics of the national political mindset (Gladarev and Lankila 2013, Ylä-Anttila and Luhtakallio, 2016). Using PJA in this study revealed the overarching priorities that guide different energy policy makers, and thereby illustrated that this method may reveal the very concrete ideas behind the often complex and hazy world of Russian strategic discourses.

Knowledge about the values and priorities directing target programs or innovative pilot projects is important because they are likely to last longer even when they end up being smothered by the various practical obstacles facing them, such as inadequate investments. These values influence what kind of arguments are more likely to count as valid and what norms are expected to be followed, thus directing the course of future discussions on the subject. The approach has revealed that the policy 
documents mostly emphasize material, concrete issues, creating opportunities for pilot projects that profit from niches and preferring supporting the existing energy networks instead of restructuring them. While this type of development is similar to that of other countries, the almost total lack of aspects associated with ecological, domestic, personal and even civic value is noteworthy. With these dimensions absent already from the discursive level of the Russian energy policies, it does not seem probable that the structural problems plaguing the Russian renewable energy development, stemming from incoherent and insufficient development and lack of a long-term, holistic vision, could be solved in the near future. It also seems likely that the link between increasing energy efficiency and renewable energy use appears mainly on paper, since developing this link from legislation into functional practices would require the type of far-sighted, exhaustive vision of a more low-carbon society that would usually also include more ecological and social issues.

After mapping these values, it is also possible to find out something about how the Russian state views the future of its Arctic territories as a whole. The fact that justification claims focus on the demands of the Russian industry and the modernization of the whole economy indicates that, first and foremost, the direction of the future development of the region is determined by the needs and priorities of the ruling powers, not those of the region itself. The Northern energy delivery system was initially put up in order to help 'conquering' the Arctic and ensuring the state's presence there (Øverland, 2010). Even though it is now planned to be partially replaced by local and renewable fuels, the reasons behind these actions seem very similar. In other words, local grass root projects in the Arctic may affect the prevailing conditions and give renewable energy its first success stories, but mainly against the background of larger national projects. 


\section{REFERENCES}

Aalto, P., ed., 2012. Russia's Energy Policies. Cheltenham, UK: Edward Elgar.

Boltanski, L. and Thévenot, L., 2006. On Justification. Princeton: Princeton University Press.

Binder, C., Mühlemeier, S., Wyss, R., 2017. An Indicator-Based Approach for Analyzing the Resilience of Transitions for Energy Regions. Part I: Theoretical and Conceptual Considerations. Energies, 10 (1): 36.

Boute, A., 2012. Modernizing the Russian district heating sector: Financing energy efficiency and renewable energy investments under the new federal heat law. Pace Environmental Law Review, 29 (3), 746-810.

Boute, A., 2013. Renewable Energy Federalism in Russia: Regions as New Actors for the Promotion of Clean Energy. Journal of Environmental Law. Retrieved from: http://jel.oxfordjournals.org/content/early/2013/05/30/jel.eqt005.abstract

Bridge, G., 2014. Energy (in)security: world-making in an age of scarcity, The Geographical Journal, 181 (4), 328-339.

Cherp, A., Jewell, J., 2011. The three perspectives on energy security: intellectual history, disciplinary roots and the potential for integration. Current Opinion in Environmental Sustainability, 3, 202-212.

Costantini, V., Gracceva, F., Markandya, A., Vicini, G., 2007. Security of energy supply: comparing scenarios from a European perspective. Energy Policy, 35(1), 210-226.

Energy Charter Protocol on Energy Efficiency and Related Environmental Aspects PEEREA [online]. European Energy Charter, 2007. Retrieved from: http://www.energycharter.org/fileadmin/DocumentsMedia/EERR/EERRRussia_ 2007_en.pdf

Geels, FW., 2002. Technological transitions as evolutionary reconfiguration pro-cesses: A multi-level perspective and a case-study. Research Policy, 31 (8-9), 12571274. 
Geels, FW., 2012. A socio-technical analysis of low-carbon transitions: Introducing the multi-level perspective into transport studies. Journal of Transport Geography, 24. 471-482.

Gladarev, B., Lonkila, M., 2013. Justifying Civic Activism in Russia and Finland. Journal of Civil Society, 9 (4), 375-90.

Government of Karelia, 2016. В Карелии подписано Соглашение о строительстве Белопорожских ГЭС и дан старт реализащии первого на территории России проекта банка БРИКС 11 October. Retrieved from: http://www.gov.karelia.ru/gov/News/2016/10/1011_09.html

Greene, D., 2010. Measuring energy security: can the United States achieve oil independence? Energy Policy, 38, 1614-1621.

Heininen, L., 2011. Arctic Strategies and Policies Inventory and Comparative Study. Arctic Strategies and Policies: Inventory and Comparative Study. Akureyri: The Northern Research Forum and University of Lapland Press.

IPB Inc., 2015. Russia Energy Policy Laws and Regulations. Handbook Volume 1 Oil and Gas: Strategic Information and Basic Regulation. World Business and Investment Library. Washington, DC: IPB, Inc.

IRENA, 2017, April. Remap 2030 Renewable Energy Prospects for Russian Federation, Working paper, Abu Dhabi: IRENA.

Jewell, J., 2011. Measuring Short-Term Energy Security. (Paris: OECD/IEA)

Jordan-Korte, K., 2011. Government Promotion of Renewable Energy Technologies: Policy Approaches and Market Development in Germany, the United States, and Japan. Wiesbaden: Gabler Verlag.

Jørgensen, U., 2012. Mapping and navigating transitions — The multi-level perspective compared with arenas of development. Research Policy, 41 (6), 996-1010.

Kireeva, A., 2014. Remote villages in Northwest Russia making enviable use of renewable energy [online]. Bellona.org. Retrieved from: http://bellona.org.

Koopmans, R., 2006. Codebook for the analysis of political mobilisation and communication in European public spheres [online]. 5th Framework Programme of the European Commission. Retrieved from: http://europub.wzb.eu/Data/Codebooks\%20questionnaires/D2-1claimscodebook.pdf

Øverland, I., 2010. The Siberian Curse: A Blessing in Disguise for Renewable Energy? Sibirica, 9 (2), 1-20. 
Øverland, I., Kjærnet, H., 2009. Russian Renewable Energy. Farnham, Surrey: Ashgate.

Pristupa, A., Mol, A., 2015. Renewable energy in Russia: The take off in solid bioenergy? Renewable and Sustainable Energy Reviews, (50), 315-324.

Rosatom newsletter 2016. The World Is the Limit. September 2016. Retrieved from: http://rosatomnewsletter.com/the-world-is-the-limit.html

Rotmans, J., Kemp, R., Van Asselt, M. 2001. More evolution than revolution: transition management in public policy. Foresight, 3 (1), 15-31.

Scott, W., 1995. Institutions and Organizations. Thousand Oaks: SAGE.

Seto, K., Davis, S., Mitchell, R., Stokes, E., Unruh, G., Ürge-Vorsatz, D., 2016. Carbon Lock-In: Types, Causes, and Policy Implications. Annual Review of Environment and Resources, 41, 425-452.

Turton, H., Barreto, L., 2006. Long-term security of energy supply and climate change. Energy Policy, 34(15), 2232-2250.

Tynkkynen, N., Aalto, P., 2012. Environmental Sustainability of Russia’s Energy. In: Aalto, P. Russia's Energy Policies: National, Interregional and Global Level. Cheltenham, UK: Edward Elgar. 92-114.

Tynkkynen, V-P., 2014. Russian Bioenergy and the EU's Renewable Energy Goals: Perspectives of Security in Russian Energy and Security up to 2030. In: Tynkkynen, V-P. and Oxenstierna, S. Russian Energy and Security up to 2030. Oxon: Routledge. 95-113.

Unruh, G., 2000. Understanding carbon lock-in. Energy Policy, 28 (12), 817-830.

Vasileva, E., Viljainen, S., Sulamaa, P., Kuleshov, D., 2015. RES support in Russia: Impact on capacity and electricity market prices. Renewable Energy, 76, 82-90.

Vergragt, P., Markusson, N., Karlsson, H., 2011. CCS, BECCS and the escape from carbon lock-in. Global Environmental Change, 2 (2), 282-292.

WWF, 2017, March. Renewable Energy in Off-Grid Settlements in the Russia Arctic, report, Moscow: Berdin, V.Kh., Kokorin, A.O., Yulkin, G.M., Yulkin.

Yergin, D., 2006. Ensuring energy security [online]. Foreign Affairs March/April. Available from: https://www.foreignaffairs.com.

Ylä-Anttila, T., Kukkonen, A., 2014. How arguments are justified in the media debate on climate change in the USA and France. International Journal of Innovation and Sustainable Development, 8(4), 394-408.

Ylä-Anttila,T., Luhtakallio, E., 2016. Justifications analysis: understanding moral evaluations in public debates. Sociological Research Online. vol 21(4), 1-15. 


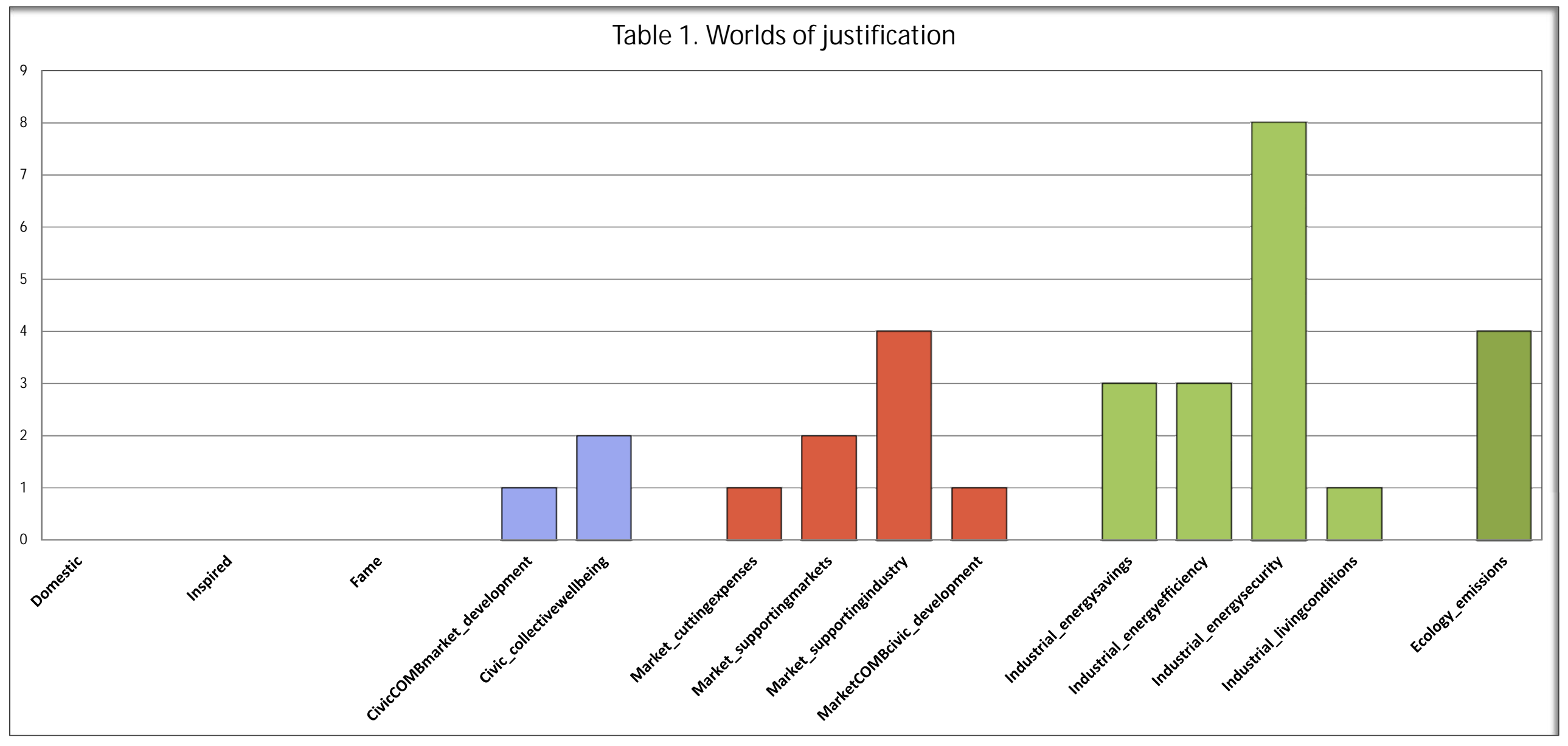

